\title{
DAMPAK KERJASAMA LUAR NEGERI PEMERINTAH KABUPATEN KAMPAR DENGAN MALAYSIA TECHNOLOGY DEVELOPMENT CORPORATION
}

\author{
Irdayanti \\ Weni Desti Febrian
}

Fakultas Ekonomi dan Ilmu Sosial

Universitas Islam Negeri Sultan Syarif Kasim

irdayanti@uin-suska.ac.id

\begin{abstract}
This study aims to determine the impact of foreign cooperation carried out by the Kampar district government with the Malaysia Technology Development Corporation to build integrated palm oil crude which will later produce various product variants from oil palm in Kampar Regency so as to be able to provide economic contributions to the community later. This collaboration refers to Law No. 24 of 2000 concerning International Agreements must be consulted and coordinated with the Minister of Finance, meaning that the regional government has the right to conduct foreign cooperation with the approval of the Ministry of Foreign Affairs. To analyze the success of the implementation of a public policy can be measured from the process of achieving the final results (outcomes), which is achieved or not the goals to be achieved. In accordance with the concept put forward by Grindle, where the measurement of the success of the implementation of the policy can be seen from two things process and results. This study uses a qualitative approach with methods of data collection through interviews, documentation and observation. The results of this study suggest that the achievement of goals can be said to not be implemented. This was seen from the 5 years running after the signing of the MoU was unable to implement the desired palm oil mill at the beginning of the collaboration. no physical changes to the construction of the PKS were found nor Psychological impacts from the community, namely in the form of disappointment with the government that has not been able to make a policy that is able to contribute to the community's economic contribution.
\end{abstract}

Keywords: foreign cooperation, policy impact, and Kampar district

\section{Abstrak}


Penelitian ini bertujuan untuk mengetahui dampak kerjasama luar negeri yang dilakukan oleh pemerintah kabupaten Kampar dengan Malaysia Technology Development Corporation untuk membangun integrated palm oil crude yang nantinya akan menhasilkan berbagai varian produk dari kelapa sawit yang ada di Kabupaten Kampar sehingga mampu memberikan kontribusi ekonomi bagi masyarat nantinya. Kerjasama ini mengacu pada UU No. 24 Tahun 2000 tentang Perjanjian Internasional wajib dikonsultasikan dan dikoordinasikan dengan Mentri artinya pemerintah daerah berhak melakukan kerjasama luar negeri atas persetujuan Kementrian Luar Neger. Untuk mengalisa keberhasilan implementasi suatu kebijakan publik dapat diukur dari proses pencapaian hasil akhir (outcomes), yaitu tercapai atau tidaknya tujuan yang ingin diraih. Sesuai dengan konsep yang dikemukakan Grindle, dimana pengukuran keberhasilan implementasi kebijakan tersebut dapat dilihat dari 2 hal proses dan hasil. Penelitian ini menggunakan pendekatan kualitatif dengan metode pengumpulan data melalui wawancara, dokumentasi dan observasi. hasil penelitian ini mengugkapkan bahwa pencapaian tujuan dapat dikatakan tidak terlaksana. Hal ini dilihat dari 5 tahun berjalan setelah penandatangan MoU tidak mampu untuk mengimplementasikan pabrik kepala sawit yang diinginkan pada awal kerjasama. tidak ditemukan perubahan fisik terhadap pembangunan PKS juga ditemukan dampak Psikologis dari masyarakat yaitu berupa kekecewaan terhadap pemerintah yang belum mampu membuat kebijakan yang mampu member kontribusi ekonomi kepada masyarakat.

\section{Keywords: kerjasama luar negeri, dampak kebijakan, dan kabupaten Kampar}

\section{PENDAHULUAN}

Perkembangan globalisasi yang terjadi saat ini telah menciptakan keterkaitan dan ketergantungan antarbangsa dan antarmanusia di seluruh dunia. Salah satunya yang menghubungkannya adalah kebutuhan hidup yang terus berubah dengan sumber daya yang berbeda-beda pada setiap negara. Hal ini kemudian mendorong negara untuk membuka diri dan saling berinteraksi dalam pasar dunia demi memenuhi kebutuhan masyarakatnya.

Keinginan untuk turut serta dalam persaingan global ini tidak hanya dimiliki oleh negara, tetapi juga muncul dari pemerintah daerah di tiap negara. Indonesia yang telah memasuki era otonomi daerah juga dituntut untuk memiliki keunggulan baik komparatif maupun kompetitif agar dapat survive dan selanjutnya sukses dalam meraih peluang-peluang yang ada. Untuk meraih peluang globalisasi diatas, maka kerjasama internasional antar pelaku ekonomi dalam rangka mengoptimalkan keunggulan yang dimiliki oleh masing-masing pihak yang bekerjasama menjadi sangat penting. Beberapa daerah di Indonesia dalam perspektif ekonomi global telah menjalin 
kerjasama internasional baik dalam bentuk kerjasama sister city dan sister province. ${ }^{1}$ Selain kerjasama internasional antar pemerintah daerah, kerjasama internasionl dengan lembaga non-pemerintah (privat) juga memiliki keunikan sendiri. Salah satu kerjasama yang dilakukan adalah dibidang alih teknologi dengan pihak asing untuk pengembangan potensi daerah yang lebih baik. Oleh sebab itu informasi tentang pelaku dan proses pembentukan kerjasama menjadi hal yang sangat penting dalam rangka pengembangan kerjasama baru maupun upaya peningkatan kualitas kerjasama yang telah ada.

Kerjasama internasional yang terjalin antar negara meliputi berbagai aspek, maupun ketika highpolitic tidak lagi menjadi satu-satunya aspek penting dalam sistem internasional dan digantikan atau setidaknya disejajarkan oleh low politic, maka peranan ekonomi di dunia internasional semakin mengemuka. Kerjasama antara masyarakat internasional pun banyak didominasi oleh kerjasama ekonomi yang dimaksudkan untuk meningkatkan kesejahteraan masyarakat masing-masing Negara untuk menghadapi era globalisasi. ${ }^{2}$

Demikianlah globalisasi telah memberi pengaruh yang sangat signifikan terhadap keadaan lingkungan internasional dan dalam negeri sebuah negara, dan untuk mengimbangi arus globalisasi ini, pemerintah daerah sebagai aktor baru dalam hubungan internasional juga tidak tinggal diam. Seperti yang dilakukan oleh salah satu kabupaten di provinsi Riau, yaitu Kabupaten Kampar yang telah melakukan MoU (memorandum of understanding) dalam rangka kerjasama pembangunan "integrated palm oil crude" dengan salah satu perusahaan asal Malaysia, yaitu Malaysia Technology Development Corproration (MTDC). MTDC adalah lembaga resmi pemerintah Malaysia yang menjadi penasihat perdagangan dan pembiayaan untuk Sawipac. Adapun Sawipac merupakan perusahaan yang bergerak dibidang perkebunan dan pengoalahan sawit yang sudah berdiri sejak 1996 dan mempunyai sejumlah kebun di Indonesia dan Malaysia. ${ }^{3}$

Tujuan dari kerjasama luar negeri ini adalah membangun Pabrik Kelapa Sawit (PKS) yang diharapkan menghasilkan hingga 45 produk turunan siap jual seperti minyak goreng, sabun, mentega, pupuk, pembangkit listrik berkekuatan $20 \mathrm{MW}$ dan produk lainnya yang berbahan dasar minyak kelapa sawit tentunya kerjasama ini juga diharapkan akan mempererat hubungan antara Indonesia dengan Malaysia yang telah terjalin sejak lama. Untuk sentra produksi minyak sawit Indonesia terutama berasal dari 6 (enam) provinsi yang memberikan kontribusi sebesar 75,26\% terhadap total produksi minyak sawit Indonesia. Provinsi Riau dan Sumatera Utara merupakan provinsi sentra produksi CPO terbesar di Indonesia dengan kontribusi sebesar 26,31\% dan 16,05\%.

\footnotetext{
${ }^{1}$ Sister city atau kota kembar adalah konsep penggandengan dua kota yang berbeda lokasi dan administrasi publiK dengan tujuan menjalin hubungan budaya dan kontak sosial antar penduduk.

${ }^{2}$ Soeprapto. 1997. Hubungan Internasional: Sistem, Interaksi dan Pelaku. Jakarta: PT. Raja Grapindo Persada, hlm 155.

${ }^{3}$ Asep Dadan Muhanda dalam Sawipac Malaysia Siap Bangun Pabrik Terpadu Olahan Sawit Di Riau (online) http://industri.bisnis.com/read/20140208/99/201893/sawipac-malaysia-siap-bangunpabrik-olahansawit-di-riau diakses pada tanggal 5 April 2016, pukul 12.05 di Pekanbaru
} 
Peringkat berikutnya berturut-turut adalah Provinsi Sumatera Selatan, Kalimantan Tengah, Jambi dan Kalimantan Barat dengan kontribusi masing-masing sebesar $10,02 \%, 10,00 \%, 7,12 \%$, dan $5,77 \% .^{4}$

Jika dilihat dari prospek pembangunan agrobisnis tersebut, Kabupaten Kampar tidak kalah saing dilihat dari perkebunan kelapa sawit terluas di Propinsi Riau yakni hampir 700 ribu Ha. Selain itu juga ada 37 Pabrik Kelapa Sawit (PKS). ${ }^{5}$ Namun luasnya lahan itu belum mampu memberikan kontribusi optimal baik untuk daerah maupun masyarakat. Selama ini, produksi kelapa sawit hanya dijual dalam bentuk minyak sawit mentah (CPO) sehingga tidak memberikan nilai lebih kepada masyarakat dan daerah penghasil. Hal ini ditengarai belum adanya industri hilir yang bisa mengolah sawit menjadi berbagai produk turunan lainnya yang justru bernilai lebih jika dibandingkan minyak sawit kasar (Crude Palm Oil) saja. Jika dicermati mahalnya minyak goreng yang masuk ke kabupaten Kampar karena CPO yang dihasilkan berkeliling dulu hingga ke pulau jawa khususnya Jakarta untuk diproduksi menjadi minyak goreng baru kembali lagi ke kabupaten Kampar.

Berdasarkan kondisi lahan dan tingkat kesuburan tanah di Riau produktivitas CPO sebesar 3,9 ton per tahun per hektar. Dengan tingginya minat masyarakat untuk memiliki kebun kelapa sakit tentu akan terus menambah jumlah produksinya setiap tahun. Seiring dengan pertambahan luas areal akan diikuti dengan peningkatan produksi TBS. Kondisi ini juga akan menyebabkan kapasitas pengolahan TBS semakin dibutuhkan baik dari segi jumlah maupun dari segi kapasitas olahnya. Begitu juga untuk luas yang ada, produksinya akan bertambah karena masih banyaknya tanaman yang belum menghasilkan. Sampai tahun 2010 luas tanaman yang belum menghasilkan sebanyak 470.713 ha yang tersebar di duabelas daerah kabupaten/kota. ${ }^{6}$ Untuk itu diperlukan sebuah upaya pengembangan dibidang produksi yang tidak hanya mampu kita produksi namun dapat menghasilkan produkan baru yang lebih bermanfaat dengan nilai jual yang lebih tinggi.

Untuk menghadapi semua kendala dan menjawab persoalan yang masih dihadapi oleh petani sawit, salah satu usaha yang dilakukan untuk proses pengembangan produksi adalah kerjasama yang saat ini sedang berlangsung antara pemerintah Kabupaten Kampar dengan perusahaan milik Malaysia dengan membangun empat pabrik kelapa sawit (PKS) dan pabrik olahan sawit dengan kebutuhan investasi mencapai Rp1,6 triliun di atas lahan 41 hektare di Kabupaten Kampar. ${ }^{7}$ Pabrik olahan itu dibangun bersama PT. Sungai Pinang Malindo di Dusun Pematang Kulim Desa Pulau Birandang Kecamatan Kampar Timur dengan kapasitas

${ }^{4}$ Outlook Komoditi kelapa Sawit. Oleh Pusat data dan Informasi Pertanian Kesekretariat Jenderal. Kementrian Pertanian tahun 2014. ISSN 1907-1507. Halaman 32

${ }^{5}$ Netty Mindrayani dalam Investor Malaysia Bangun Pabrik Mentega Di Kampar (online) http://antarariau.com/berita/24556/investor-malaysia-bangun-pabrik-mentega-di-kampar+ tanggal 10 Januari 2013 diakses pada tanggal 5 april 2015, pukul 12.05 di Pekanbaru

${ }^{6}$ Almasdi Syahza. 2012. Potensi Pengembangan Industri Kelapa Sawit. Hasil Penelitian MP3EI di wilayah Riau

7Ibid, Asep 
produksi mencapai 120 ton minyak sawit mentah (CPO) per jam. ${ }^{8}$ Pabrik ini dinilai cukup untuk menampung buah sawit dari perkebunan masyarakat. Jika pabrik itu sudah beroperasi, dipastikan harga tandan buah segar (TBS) milik masyarakat di Kabupaten Kampar akan selalu stabil. Sebab, sawit mentah atau crude palm oil (CPO) yang dihasilkan PKS tidak harus dijual di ke luar Kampar namun langsung diserap oleh pabrik itu. Guna mendukung keinginan MTDC mengembangkan industri hilir kelapa sawit di Kabupaten Kampar, pihak Kabupaten Kampar akan memberikan kemudahan dalam berinvestasi, terutama menyangkut masalah perijinan. Dengan berdirinya pabrik olahan kelapa sawit di Kabupaten Kampar, tentunya akan memberikan nilai tambah kepada masyarakat dan daerah khususnya kecamatan Kampar Timur sebagai tempat pertama pembangunan PKS.

Pembangunan PKS (Pabrik Kelapa sawit) menjadi salah satu meningkatkan teknologi untuk kemaslahatan umat manusia, tentunya bertujuan memberdayakan semua Serikat petani kelapa sawit dan masayarakat kabupaten Kampar untuk memanfaatkan teknologi. MTDC dibangun untuk merangkul semua perusahaan kelapa sawit di Kabupaten Kampar untuk bersama menikmati teknologi dan menikmati hasil yang diciptakan oleh teknologi tersebut. Dalam penelitian ini dikhususkan untuk melihat dampak kerjasama luar negeri antara kabupaten Kampar dan MTDC terhadap perekonomian masyarakat di kecamatan Kampar Timur sebagai tempat dibangunnya pabrik hilir pertama kalinya.

\section{A. Metode Penelitian}

Penelitian ini menggunakan metode penelitian kualitatif dengan pendekatan deskriptif. Penelitian deskriptif berusaha menggambarkan suatu gejala sosial. Menurut Bungin $^{9}$ penelitian sosial menggunakan format deskriptif kualitatif bertujuan untuk menggambarkan, meringkaskan berbagai kondisi, situasi, atau fenomena realitas sosial yang ada di masyarakat yang menjadi objek penelitian, dan berupaya menarik realitas itu ke permukaan sebagai suatu ciri, karakter, sifat, model, tanda, atau gambaran tentang kondisi, situasi, ataupun fenomena tertentu. Dengan demikian, penelitian ini akan menjelaskan gambaran realitas dari masalah yang akan peneliti elaborasi dengan menggunakan data-data yang ada melalui metode pengumpulan data wawancara, dokumentasi dan observasi. Terdapat empat orang informan utama yang diwawancara, yaitu: 1) Kepala Sub Bagian Pangan, Pertanian dan Perikanan Kabupaten Kampar, (2) Kepala Bagian Pemerintahan dan Kesejahteraan Rakyat bagian Kerjasama Kabupaten Kampar, (3) Kepala Dinas Perkebunan, Peternakan dan Kesehatan hewan Kabupaten

\footnotetext{
${ }^{8}$ Riyan Nofitra. Kampar Kini Punya Pabrik Olahan Kelapa Sawit. 10 Maret 2015. (online) http://www.tempo.co/read/news/2015/03/10/092648727/Kampar-Kini-Punya-Pabrik-Olahan-KelapaSawit diakses pada tanggal 10 April 2015 di Pekanbaru

${ }^{9}$ Burhan, Bungin, 2007. Penelitian Kualitatif Komunikasi, Ekonomi, Kebijaka Publik, Dan Ilmu Sosial Lainnya, Edisi pertama, Cetakan ke-2, Jakarta: Kencana halaman 68
} 
Kampar, (4) Sekretaris Desa Desa Sungai Pinang kecamatan Kampar Timur serta Informan pendukung penelitian yaitu masyarakat kecamatan Kampar Timur

\section{B. Kerangka Pemikiran}

\section{Kebijakan Luar Negeri}

Pengertian kebijakan adalah rangkaian konsep dan asas yang menjadi pedoman dan dasar rencana dalam pelaksanaan suatu pekerjaaan, kepemimpinan dan cara bertindak. Istilah ini dapat diterapkan pada pemerintahan, organisasidan kelompok sector swasta serta individu. Kebijakan berbeda dengan peraturan hukum. Jika hukum dapat memaksakan atau melarang suatu perilaku, kebijkan hanya menjadi pedoman tindakan yang paling mungkin memperoleh hasil yang diinginkan.

Kebijakan atau kajian kebijakan dapat pula merujuk pada proses pembuatan keputusan-keputusan penting organisasitermasuk identifikasi berbabgai alternatifsperti prioritas program atau pengeluaran dan pemilihannya berdasarkan dampaknya. Kebijakan juga dapat diartikan sebagai mekanisme politis, manajemen financial atau administrative mencapai suatu tujuan eksplisit.

Sedangkan pengertian kebijakan luar negeri adalah merupakan strategi atau rencana tindakan yang dibentuk oleh para pembuat keputusan suatu negara dalam menghadapai negara lain atau unit politk internasional lainnya. Dikendalikan dalam kepentingan nasional.

Rosenau memberi defenisi terhadap kebijakan luar negeri sebagai berikut: "all the attitudes and activities through which organized nation societes seeks with and benefit from international environment".

Sedangkan tipe-tipe keputusan luar negeri dapat dibedakan menjadi 3 yaitu: ${ }^{10}$

1. Keputusan mikro dikenal sebagai keputusan administratif dan biasanya dibuat lebih rendah dari organisasi pemerintah, dan biasnya dikerjakan secara individu bukan oleh kepemimpinan politik. Keputusan ini sempit jangkaunnya dan rendah tingkat keseriusannya ancamannnya. Sehingga tidak membutuhkan perhatian dari pembuat keputusan tingkat atas.

2. Keputusan krisis adalah keputusan yang mirip dengan keputusan mikro, namun merupakan keputusan kecil yang melibatkan pembuatan keputusan tingkat tinggi. Keputusan ini dibuat pada situasi yang mengancam, dengan demikian keputusan ini mengandung elemen yang tidak diperhitungkan sebelumnya (surprise) dan diputuskan dalam jangka waktu yang pendek.

\section{Evaluasi Dampak Kebijakan}

Dampak adalah perubahan kondisi fisik maupun sosial sebagai akibat dari output kebijakan. Akibat dari output kebijakan ada dua macam yakni:

${ }^{10}$ Toma, Peter A dan Gorman, Robert F, 1991, International Relations : understanding global issues, Brooks/cole Publishing, California halaman 135 
1. Akibat yang dihasilkan oleh suatu intervensi program pada kelompok sasaran (baik akibat yang diharapkan atau tidak diharapkan) dan akibat tersebut mampu menimbulkan pola perilaku baru pada kelompok sasaran (impact).

2. Akibat yang dihasilkan oleh suatu intervensi program pada kelompok sasaran, baik yang sesuai dengan yg diharapkan atau tidak dan akibat tersebut tidak mampu menimbulkan perilaku baru pada kelompok sasaran (effects).

Pada sisi yang lain, Thomas R. Dye dalam Winarno ${ }^{11}$ menyatakan dampak dari suatu kebijakan mempunyai beberapa dimensi dan semuanya harus diperhitungkan dalam membicarakan evaluasi.

1) Dampak kebijakan pada masalah-masalah publik dan dampak kebijakan pada orangorang yang terlibat.

2) Kebijakan-kebijakan mungkin mempunyai dampak pada keadaan-keadaan atau kelompok-kelompok di luar sasaran atau tujuan kebijakan.

3) Kebijakan mungkin akan mempunyai dampak pada keadaan-keadaan sekarang dan keadaan di masa yang akan datang.

4) Evaluasi juga menyangkut unsur yang lain, yakni biaya langsung yang dikeluarkan untuk membiayai program-program kebijakan publik.

5) Dimensi yang terakhir dari evaluasi kebijakan adalah menyangkut biaya biaya tidak langsung yang ditanggung oleh masyarakat atau beberapa anggota masyarakat akibat adanya kebijakan publik. Sekalipun dampak yang sebenarnya dari suatu kebijakan mungkin sangat jauh dari yang diharapkan atau diinginkan, tetapi kebijakan tersebut pada dasarnya mempunyai konsekuensi-konsekuensi yang penting bagi masyarakat.

\section{Faktor Penyebab Keberhasilan dan Kegagalan Implementasi Kebijakan}

Pendekatan Meriee S. Grindle dikenal dengan Implementation as A Political and Administrative Procces. Menurut Grindle ada 2 variabel yang mempengaruhi implementasi kebijakan publik, yaitu:

Keberhasilan implementasi suatu kebijakan publik dapat diukur dari proses pencapaian hasil akhir (outcomes), yaitu tercapai atau tidaknya tujuan yang ingin diraih. Hal ini dikemukakan oleh Grindle, dimana pengukuran keberhasilan implementasi kebijakan tersebut dapat dilihat dari 2 hal, yakni:

a. Dilihat dari prosesnya, dengan mempertanyakan apakah pelaksanaan kebijakan sesuai dengan yang ditentukan (design) dengan merujuk pada aksi kebijakannya.

b. Apakah tujuan kebijakan tercapai. Dimensi ini diukur dengan melihat dua faktor, yaitu: a) Dampak atau efeknya pada masyarakat secara individu dan kelompok dan b) Tingkat perubahan yang terjadi serta penerimaan kelompok sasaran dan perubahan yang terjadi.

\footnotetext{
${ }^{11}$ Winarno, Budi. 2002. Teori dan Proses Kebijakan Publik. Yogyakarta: Media halaman 171-173
} 
Selain itu juga Jam Marse mengemukakan bahwa ada tiga faktor yang dapat menimbulkan kegagalan dalam implementasi kebijakan yaitu: ${ }^{12}$

1. Isu kebijakan. Implementasi kebijakan dapat gagal karena masih ketidaktetapan atau ketidak tegasan intern maupun ekstern atau kebijakan itu sendiri, menunjukan adanya kekurangan yang menyangkut sumber daya pembantu.

2. Informasi. Kekurangan informasi dengan mudah mengakibatkan adanya gambaran yang kurang tepat baik kepada objek kebijakan maupun kepada para pelaksana dari isi kebijakan yang akan dilaksanakannya dan hasil-hasil dari kebijakan itu.

3. Dukungan. Implementasi kebijakan publik akan sangat sulit bila pada pelaksanaanya tidak cukup dukungan untuk kebijakan tersebut.

\section{Kerjasama Luar Negeri}

Jika melihat kebijakan luar negeri yang dilakukan banyak negara saat ini berawal dari konsep kerjasama internasional oleh kaum liberal. Pada abad ke 18 dan 19 kaum liberal merasa bahwa semangat perang dan semangat perdagangan saling bertentangan. Kebanyakan perang dilakukan Negara untuk mencapai tujuan perdagangan, meski demikian perdagangan bebas melalui kerjasama merupakan cara yang jauh lebih efektif dan lebih damai untuk mencapai kemakmuran Negara, karena menurut teori keunggulan komparatif, ekeonomi Negara akan lebih baik secara material dari pada suatu Negara mencoba nasionalisme dan kepuasan sendiri. ${ }^{13}$ Sejak semula, fokus dari teori hubungan internasional adalah mempelajari tentang penyebabpenyebab dan kondisi-kondisi yang menciptakan kerjasama. Kerjasama dapat tercipta sebagai akibat dari penyesuaian-penyesuaian perilaku aktor-aktor dalam merespon atau mengantisipasi pilihan-pilihan yang di ambil oleh aktor-aktor dalam merespon atau mengantisipasi pilihan-pilihan yang diambil oleh aktor-aktor lainnya.

Kerjasama dapat tumbuh dari suatu komitmen individu terhadap kesejahteraan bersama atau sebagai usaha pemenuhan kepentingan pribadi. Kunci dari perilaku kerjasama ada pada sejauh mana setiap pribadi percaya bahwa yang lainnya akan bekerja sama. Sehingga isu utama dari teori kerjasama adalah didasarkan pada pemenuhan kepentingan pribadi, dimana hasil yang menguntungkan kedua belah pihak dapat diperoleh dengan bekerja sama dari pada dengan usaha sendiri atau dengan persaingan. Di dalam jargon ekonomi politik kaum liberal beranggapan bahwa masyarakat itu seperti suatu permainan dimana semua pemain bisa memperoleh keuntungan dari taruhan yang dipertaruhkan (positive sum-game). Contohnya adalah pertukaran barang dan jasa di pasar yang saling menguntungkan. ${ }^{14}$

\footnotetext{
${ }^{12}$ Abdul Wahab, Solichin, 1997. Evaluasi kebijakan Publik. Penerbit FIA. UNIBRAW dan IKIP Malang halaman 19

${ }^{13}$ Scott Burchill dan Andrew Linklater. 1996 (ed. Revisi). Teori-teori Hubungan Internasional. Bandung: Nusa Media, halaman 48

${ }^{14}$ Umi Oktyari R, MA. 2006. Laporan Pelatihan Non Gelar. Pekanbaru: Universitas Riau, halaman 25
} 
Serta jika dilihat dengan perkembangan globalisasi data ini, Negara bukan satu-satunya aktor dalam sistem internasional, aktor non negara seperti perusahaan asing juga mampu berperan dalam usaha kerjasama internasional.

Kerjasama internasional mencakup kerjasama luar negeri yang dapat dilakukan negara dan aktor non negara, sehingga bisa dijelaskan bahwa pengertian Kerjasama dengan Luar Negeri adalah Kesepakatan antara Kepala Daerah dengan Pihak Luar Negeri yaitu Pemerintah Negara Bagian atau Pemerintah Daerah di Luar Negeri, Perserikatan Bangsa-bangsa termasuk Badan-badannya dan Organisasi/Lembaga Internasional lainnya, Organisasi/Lembaga swadaya masyarakat luar negeri serta Badan Usaha Milik Pemerintah Negara/Negara Bagian/Daerah di Luar Negeri, dan Swasta di Luar Negeri.

Ada beberapa alasan mengapa negara melakukan kerjasama dengan negara melakukan kerjasama dengan pihak lainnya:

1. Peningkatan kesejahteraan ekonomi dapat dilakukan dengan kerjasama luar negeri disebebabkan kelangkaan dalam negeri dalam memproduksi suatu barang.

2. Mampu mengurangi biaya dengan kerjasama luar negeri

3. Karena adanya masalah-masalah yang mengancam keamanan bersama.

Dalam proses kerjasama internasional terdapat beberapa prinsip-prinsip hukum umum sebagai landasan dalam hukum internasional yaitu azas-azas hukum yang mendasari sistem hukum positif yang sudah melembaga dan tentunya prinsip-prinsip hukum umum terkait dengan perjanjian internasional ${ }^{15}$ salah satunya adalah prinsip permasaan hak.

Kerjasama internasional pada umumnya berlangsung pada situasi-situasi yang bersifat desentralisasi yang kekurangan institusi-institusi dan norma-norma yang efektif bagi unit-unit yang berbeda secara kultur dan terpisah secara geografis, sehingga kebutuhan untuk mengatasi masalah yang menyangkut kurang memadainya informasi tentang motivasi-motivasi dan tujuan-tujuan dari berbagai pihak sangatlah penting. Interaksi yang dilakukan secara terus-menerus, berkembangnya komunikasi dan transpotasi antar negara dalam bentuk pertukaran informasi mengenai tujuantujuan kerjasama, dan pertumbuhan berbagai institusi yang walaupun belum sempurna dimana pola-pola kerjasama menggambarkan unsur-unsur dalam teori kerjasama berdasarkan kepentingan sendiri dalam sistem internasional anarkis.

\section{Kerjasama Luar Negeri Oleh Pemerintah Daerah}

Perkembangan yang pesat di hampir seluruh aspek kehidupan manusia telah melahirkan beragam bentuk kerjasama di dunia. Motivasi utama dibentuknya sebuah kerjasama biasanya lahir dari kesadaran bahwa setiap Negara bangsa di dunia tidak selamanya dapat mengandalkan potensi dalam negerinya untuk memenuhi kebutuhannya. Akan tetapi dapat dipenuhi oleh Negara lain melalui sebuah kerjasama. Seiring perkembangan kerjasama itu, lahir pula aktor-aktor baru seperti pemerintah

\footnotetext{
${ }^{15}$ Roisah, Kholid.2015. Hukum Perjanjian Internasional Teori dan Praktik. Malang: Setara Press, halaman 18
} 
daerah, jika selama ini kerjasama hanya dilakukan antar pemerintah pusat sebuah Negara, maka sekarang ini pemerintah daerah pun semakin aktif turut serta dalam kerjasama dengan luar negeri. Tidak terkecuali daerah- daerah yang ada di wilayah Indonesia. Diharapkan Daerah mampu meningkatkan dan mengembangkan kerjasama daerah dan luar negeri. Karena melalui kerjasama tersebut dapat tercipta kesejahteraan masyarakat.

Untuk dapat mendorong kerjasama Daerah dengan Luar Negeri, mengacu pada UU No. 24 Tahun 2000 tentang Perjanjian Internasional wajib dikonsultasikan dan dikoordinasikan dengan Mentri. ${ }^{16}$ Kerjasama yang dilakukan suatu pemerintah daerah dan luar negeri merupakan suatu rangkaian kegiatan yang terjadi karena ikatan formal antara pemerintah daerah dengan pihak luar negeri untuk bersama sama mencapai suatu tujuan tertentu dalam rangka penyelenggaraan pemerintah daerah. Namun hubungan dan kerjasama luar negeri oleh pemerintah Daerah harus diselenggarakan sesuai dengan politik luar negeri dan tidak membentur rambu-rambu yang sudah ditetapkan.

Selain itu Dasar Hukum kerjasama Luar Negeri oleh Pemerintah Daerah adalah UU No 3 tentang Pemda (Pasal 42): DPRD mempunyai tugas dan wewenang memberikan, antara lain: pendapat dan pertimbangan kepada pemerintah daerah terhadap rencana perjanjian internasional di daerah.

\section{Prinsip-prinsip Kerjasama Luar Negeri}

Dalam kerjasama luar negeri memiliki beberapa prinsip yang harus dilaksanakan, antara lain:

1. Kerjasama dilaksanakan melalui hubungan kelembagaan formal antara Badan Litbang dengan mitra kerjasama dengan tetap mengacu pada prioritas program penelitian dan pengembangan pertanian nasional.

2. Kerjasama dilaksanakan atas dasar persamaan kedudukan yang saling menguntungkan serta tidak bertentangan dengan peraturan perundang-undangan yang berlaku.

3. Kerjasama dilaksanakan dengan sistem kontrol yang ketat terutama menyangkut : (a) ijin dari Instansi Pemerintah yang berwenang; (b) penggalian data/informasi diluar kontek perjanjian kerjasama penelitian; (c) penggunaan sumber plasma nutfah, peta dan lain lain yang dapat merugikan dan membahayakan kepentingan/keamanan nasional

\section{Bentuk Kerjasama Luar Negeri Oleh Pemerintah Daerah}

1. Kota Kembar/Sister City

Kerjasama Kota Kembar/Sister City adalah konsep penggandengan dua kota yang berbeda lokasi dan administrasi politik dengan tujuan menjalin hubungan budaya dan kontak sosial antarpenduduk. Kota kembar umumnya memiliki persamaan keadaan demografi dan masalah-masalah yang dihadapi. Konsep kota kembar bisa

${ }^{16}$ Panduan Umum Tata Cara Hubungan dan Kerjasama Luar Negeri oleh Pemerintah Daerah (Revisi). 2006. Departemen Luar Negeri Republik Indonesia, halaman 18 
diumpamakan sebagai sahabat pena antara dua kota. Hubungan kota kembar sangat bermanfaat bagi program pertukaran pelajar dan kerjasama di bidang budaya dan perdagangan.

2. Kerjasama Teknik Luar Negeri

Kerjasama teknik luar negeri merupakan kerjasama pemeritah daerah dengan negara atau badan/lembaga asing dalam rangka upaya meningktakan kemampuan dan keterampilan sumber daya manusia melalui pelatihan, alih teknologi dan pertukaran tenaga ahli, guna mendukung pelaksanaan pembangunan daerah, khususnya peningkatan kesejahteraan dan upaya pengentasan kemiskinan.

\section{Aspek Politik dan Ekonomi Pelaksanaan Kerjasama Daerah Dengan Pihak Luar Negeri}

Dalam era globalisasi sekarang ini pelaksanaan otonomi daerah tidak bisa dipisahkan dalam konteks hubungan internasional dengan aktor negera atau non negara. Saat ini pemerintah daerah baik level propinsi maupun kabupaten/kota telah melaksanakan kerjasama dengan pihak luar negeri demi memajukan pembangunan sosial, ekonomi dan budaya. Meskipun hubungan luar negeri menjadi kewenangan pusat, secara tak terhindarkan pemerintah daerah harus menghadapi proses liberalisasi arus barang, jasa, modal dan tenaga kerja dengan segala implikasinya terhadap politik luar negeri.

Dewasa ini pemerintah daerah dituntut untuk memberikan respon terhadap tantangan dan peluang yang ditawarkan oleh dunia internasional dalam arti positif dan negatif. Secara positif hubungan luar negeri yang dilakukan pemerintah daerah bisa mendukung kebijakan pemerintah pusat tetapi secara negatif hubungan itu bisa juga membawa kerugian bagi rakyat Indonesia melalui proses ekploitasi akibat ketidaksadaran posisi dan kurangnya koordinasi dengan pemerintah pusat. Pengaturan tentang otonomi daerah yang berlaku saat ini melalui UU Nomor 32 Tahun 2004 disebutkan bahwa kesepakatan internasional yang dilakukan pemerintah daerah dengan pihak luar negeri dimaksudkan untuk mempromosikan kepentingan daerah. ${ }^{17}$

\section{PEMBAHASAN}

\section{A. Implementasi Kebijakan}

Dalam penelitian ini, dampak kerjasama luar negeri diukur dari berhasil atau tidaknya implementasi kerjasama sehingga dapat dianalisis untuk mengkonfirmasi jawaban informan dengan fakta dilapangan. Adapun indikator-indikator yang digunakan peneliti untuk melihat implementasi kerjasama yaitu proses kebijakan dan tujuan kerjasama. Sehingga dapat dilihat tingkat keberhasilan implementasi kebijakan dan dampak dapat dianisis lebih baik. Berikut adalah analisis implementasi kebijakan kerjasama luar negeri pemerintah Kabupaten Kampar dengan Malaysia Technology Development Corporation menurut Meriee S. Grindle.

${ }^{17}$ Jemadu, Aleksius. 2008. Politik Global, teori dan Praktek. Yogyakarta: Graha Ilmu, halaman 128 


\section{Proses Kerjama Luar Negeri}

Proses kerjasama dilihat dari kesesuaian pelaksanaan kebijakan sesuai dengan yang ditentukan (design) dengan merujuk pada aksi kebijakannya. Implementasi kebijakan dapat gagal karena masih ketidaktetapan atau ketidaktegasan intern maupun ekstern atau kebijakan itu sendiri, menunjukan adanya kekurangan yang menyangkut sumber daya pembantu

Jika melihat isu kebijakan yang diangkat oleh kerjasama ini yaitu pembangunan pabrik kelapa sawit (PKS) di Kampar yang diharapkan menghasilkan hingga 45 produk turunan siap jual seperti minyak goreng, sabun dan mentega, berpotensi mensejahterakan masyarakat di kabupaten Kampar secara merata. Pembangunan PKS untuk produksi 45 turunan siap jual merupakan model pengembangan kelapa sawit terbaru yang memiliki keunggulan dan memiliki positif untuk seluruh kalangan baik pemerintah, pengusaha bahkan yang paling utama adalah masyarakat. Seperti dikutip dari riaugreen.com Direktur PT. Sungai Pinang Malindo mengatakan:

"kalau pabrik kelapa sawit ini nantinya akan mengelola 60 ton perjam dan mengelola CPO menjadikan minyak goring dan kita juga nantinya akan menerima tenaga kerja dari Kabupaten Kampar, pembangunan PKS ini juga salah satu untuk mendukung terwujudnya program Bupati Kampar"

Terlebih lagi PKS tersebut berada dekat dengan lahan perkebunan sawit milik masyarakat sehingga akan memangkas biaya transportasi angkutan kelapa sawit. Pabrik tersebut berada di Dusun Pematang Kulim, Desa Pulau Birandang, Kecamatan Kampar Timur, Kampar. Setelah dilakukan observasi lapangan dan wawancara pada pihak desa dapat informasikan bahwa kerjasama tidak berjalan dengan baik hingga 2 tahun berjalannya sejak peletakan batu pertama PKS tersebut.

Ada beberapa hal yang dapat dianalisis untuk menjelaskan tidak terwujudnya kerjasama Kabupaten Kampar dengan pihak Malaysia.

\section{Lemahnya Perjanjian MoU yang Telah Ditandatangani}

. Jika melihat dari perjanjian kerjasama yang ditandatangani oleh pemerintah Kabupaten Kampar dalam hal ini adalah Bupati dan Kepala konsultan MTDC adalah berbentuk MoU (Memorandum of Understanding). Perjanjian di dalam hukum internasional memainkan peran yang sangat penting. Selain sebagai sumber hukum formil, perjanjian juga mencantumkan hak dan kewajiban masing-masing subjek hukum.

Memorandum Saling Pengertian (Memorandum of Understanding) merupakan salah satu model dokumen yang memiliki sifat khas/typical. Terdapat praktek negara, khususnya pada negara-negara common law system, yang berpandangan bahwa MOU adalah non-legally binding dan perlu dibedakan dengan Treaties. Namun praktek negara-negara lain termasuk Indonesia menekankan prinsip bahwa setiap persetujuan yang dibuat antara negara (termasuk MOU) memiliki daya mengikat seperti Treaties. Para ahli berpendapat bahwa istilah MOU digunakan dengan alasan politis yaitu ingin 
sedapat mungkin menghindari penggunaan Agreement yang dinilai lebih formal dan mengikat. Adanya pengertian MOU yang non-legally binding dalam praktek beberapa negara akan menimbulkan suatu situasi bahwa satu pihak menilai dokumen tersebut sebagai perjanjian internasional yang mengikat namun pihak yang lain menganggap dokumen itu hanya memuat komitmen politik dan moral.

Artinya MoU yang ditandangani oleh kedua belah pihak masuk dalam kategori soft law yang tidak mengikat secara kuat. Hal ini juga senada dijelaskan oleh Kasubag Pangan, Pertanian dan Perikanan, Yohanes Purwoko S.P, M,Si bahwa:

"tidak terlaksananya kerjasama ini disebabkan oleh kedua belah pihak hanya sebagai fasilitator bagi pihak ketiga, yaitu mitra usaha yang ingin bekerjamasa melalui kedua belah pihak"

Jika dianalisis lebih lanjut MoU yang telah disepakti juga menyebutkan di Pasal 2 tentang Ruang Lingkup Kerjasama no 3 yang menyebutkan: "dimana hal tersebut diperlukan, para pihak harus bertindak sebagai fasilitator dari setiap perusahaan Malaysia dan Perusahaan Indonesia dalam hal diskusi, negosiasi dan pelaksanaan perjanjian kerjasama". Dengan ditunjuknya dua pihak sebagai fasilitator artinya kerjasama yang dilakukan dibawah koordinasi fasilitas kedua belah pihak. Untuk mengukur tingkat legislasi dari sebuah perjanjian atau kerjasama internasional dapat dilihat dari obligasi, delegasi dan presisi. ${ }^{18}$

Pertama, kewajiban diartikan sebaga keterikatan negara untuk memenuhi kewajiban atau komitmen yang tertera dalam sebuah perjanjian, dengan demikian perilaku negara dibatasi perjanjian dan komitmen oleh sebab itu dalam kerjasama ini ketikakedua belah pihak hanya sebagai fasilitator makanya kewajibannya hanya memfasilitasi bukan pelaksana di lapangan. Kedua, delegasi yaitu sejauh mana aktor hubungan internasional memberikan otoritas kepada pihak ketiga (termasuk disini pengadilan internasional). Yang dimaksud otoritas disini adalah adanya jaminan kekuasaan bagi pihak ketiga untuk mengimplementasikan aturan. Jika dilihat dari MoU yang dilakukan oleh Kabupaten Kampar dengan MTDC jika terjadi sengketa antara antara pihak pelaksanaan kerjasama diselesaikan secara damai melalui musyawarah. Dari sini dapat dilihat bahwa tidak ada pihak ketiga dalam hal ini pengadilan internasional diikutsertakan. Ketiga, presisi aturan-aturan secara jelas dan tidak ambigu, menjadi acuan bagi tingkah laku aktor yang terikat oleh hukum tersebut.

Semakin tinggi tingkat obligasi, presisi dan delegasi semakin tinggi pula legislasi suatu hukum internasional. Dari paparan di atas dapat dianalisis bahwa tingkat legislasi MoU antara Kabupten Kampar dengan MTDC masih lemah. Dapat terlihat pada obligasi dan delegasi yang masih lemah untuk mengikat kerjasama ini menjadi terwujud. Ini yang mengakibatkan salah satu faktor mengapa pelaksanaan kerjasama tidak berjalan.

${ }^{18}$ Log cit, Abbot W Kennet, R Keohane, Andrew moravsicik, anne-Marie slaughter dan Duncal snidal dalam Kholis Roisah, halaman 119 


\section{Isu Penanaman Modal Asing}

Selain masalah perjanjian kerjasama yang lemah, masalah lain timbul dari pihak mitra kerjasama yaitu PT Sungai Pinang Malindo yang diharapkan dapat mewujudkan kerjasama ini. Masalah tersebut adalah isu penanaman modal asing. Ide awal dari kerjasma ini adalah untuk membuat PKS hilir yang artinya semua produksi kelapa sawit dikumpulkan pada pada pabrik kemudian keluarannya tidak hanya berbentuk minyak kelapa sawit namun varian produk yang nantinya akan membantu masyarakat dalam pemenuhan kebutuhan. Namun fakta dilapangan para investor enggan untuk bekerjasama dalam pembuatan pabrik hilir dan lebih berminat untuk membentuk perusahaan hulu yang artinya mereka memproduksi sendiri dan mengekspor senidri. Meskipun banyak investor di sektor perkebunan kelapa sawit, tidak banyak pengusaha yang mau membangun industri hilir pengolahan produk turunan. Pengusaha yang memilih membuka kebun kelapa sawit mulai dari nol. Dengan usia tiap pohon rata-rata 25 tahun, mulai berproduksi umur delapan tahun. Ini termasuk dalam pendapatan riil tanpa risiko terlalu besar.

Namun bila memilih membuka pabrik pengolahan produk turunan, para investor harus menyiapkan ahli dan tenaga produksi secara massal, ini ada risikonya jika tidak bisa mengelola dengan baik pabrik itu bisa rugi, alasan ini yang menjadi ide awal kerjasama luar negeri pemerintah Kabupten Kampar dengan MTDC Malaysia. Diharapkan dengan adanya kerjasama ini banyak investor yang akan menjalin kerjasama dalam pembuatan perusahaan hilir di Kabupaten Kampar.

Seperti yang dijelaskan oleh (mantan) Bupati Kampar Jefrey Noer yang dikutip dari goriau.com:

Rencana pembangunan PKS ini sebenarnya telah dirancang sejak 2013. Sebagai komitmen, Pemda Kabupaten Kampar kemudian mempermudah segala proses perizinan bahkan hanya selesai dalam waktu tujuh hari. Kenapa lama, itu karena Pemerintah Pusat menyetujui perizinan yang sampai lebih setahun"

Kepala BPMPD Provinsi Riau Irhas Irfan mengatakan:

"investasi di Riau memang didominasi asing. Dari Januari hingga September 2014, penanaman modal asing (PMA) sebesar 11,57 triliun. Sedangkan, penanaman modal dalam negeri (PMDN) hanya Rp 6,27 triliun"

Menurutnya lagi investor asing mulai masuk ke Riau sejak 20 tahun lalu. Sebelum di Indonesia, kelapa sawit lebih dulu berkembang di Malaysia. Namun, karena Malaysia kekurangan lahan, para investor akhirnya mulai mengembangkan bisnisnya di Riau yang letaknya bertetangga. ${ }^{19}$ Namun sepertinya isu penanaman modal asing menjadi kendala dalam mendapatkan izin di pemerintahan pusat.

\footnotetext{
${ }^{19}$ Menonton Kekayaan Asing di Negeri Sendiri dipublish tanggal 4 Desember 2014 dalam http://www.republika.co.id/berita/koran/podium/14/12/04/ng218816-menonton-kekayaan-asing-dinegeri-sendiri diakses pada tanggal 4 Agustus 2017
} 
Pemerintah pusat sebenarnya telah membuat aturan yang lebih ketat untuk menerbitkan izin bagi investor asing. Ia menjelaskan, semua izin prinsip bagi PMA dikeluarkan oleh Badan Koordinasi Penanaman Modal (BKPM) pusat. Namun, untuk izin lokasi, dikeluarkan oleh pemerintah daerah setempat. Inilah yang menjadi kendala dalam pembentukan Pabrik hilir dari kerjasama luar negeri Malaysia dan MTDC, seperti yang disampaikan oleh Kepala Dinas Perkebunan Kabupaten Kampar, Bustan:

"hingga kini belum terwujudnya kerjasama pembuatan pabrik tersebut terbentur oleh izin di pusat terkait penanaman modal asing, detailnya seperti apa kurang tau untuk kerjasama ini."

Penguasaan kelapa sawit oleh asing di Provinsi Riau sudah mengkhawatirkan. Pemerintah lebih selektif lagi dalam menerbitkan izin prinsip bagi perusahaan asing. Jika tidak, pengusaha dalam negeri yang akan tertinggal dari pengusaha asing.

\section{Pencapaian Tujuan}

Di dalam pencapian tujuan tidak hanya melihat pada design awal namun yang juga paling berpengaruh adalah bagaimana cara mewujudkannya. Jika melihat perkembangan pelaksanaan kerjasama dimana ide awalnya adalah membentuk Perusahaan Kelapa Sawit (PKS) yang rencananya akan dijalankan PT Sungai Pinang Malindo (SPM) dengan penawaran investasi integrated palm oil (pabrik kelapa sawit terintegrasi) yang mana telah ditetapkan pembangunannya di kecamatan Kampar Kiri desa Sungai Pinang pada awal tahun 2015, namun hingga saat ini perusahaan tersebut urung dibangun. Sesuai dengan pernyataan dari sekretaris desa Sungai Pinang, Nasrul menjelaskan:

"saya pernah mendengar pembangunan PKS memang ada, sayapun ikut dalam acara peletakan batu pertama PKS tersebut di daerah Pematang Kulim, pejabat daerah juga banyak yang hadir sekitar tahun 2015, namun hingga saat ini tidak pernah ada tindak lanjut dari pembangunan PKS tersebut. Malah saya dengar banyak penduduk yang bekerja di daerah itu sebagai petani cabe"

Dari penjelasan tersebut dapat dijelaskan bahwa pembangunan PKS hilir yang telah ditentukan untuk mewujudkan kerjasama tidak pernah mengalami perkembangan. Sedangkan PKS inilah yang nantinya akan menjembatani kerjasama dari pemerintah kabupaten Kampar dan MTDC. Harapan yang besar terhadap pabrik ini menjadi solusi terhadap peningkatan investasi bidang industri hilir kelapa sawit di Riau.

Selain itu kurangnya dukungan dengan mudah mengakibatkan adanya gambaran yang kurang tepat baik kepada objek kebijakan maupun kepada para pelaksana dari isi kebijakan yang akan dilaksanakannya dan hasil-hasil dari kebijakan itu. Kerjasama yang melibatkan 2 pihak memiliki keberhasilan jika kedua pihak dapat bekerja sama dengan baik. Selain itu kedua pihak harus mampu saling mendukung dalam berbagai hal yang berkaitan dengan kerjasama selama itu untuk kepentingan bersama. Hal ini sangat penting karena kerjasama akan sia-sia jika hanya salah satu pihak saja yang 
merespon dan bekerja dengan baik, juga hal ini akan sia-sia jika kedua pihak tidak saling mendukung.

Tidak hanya itu, kedua pihak harus memiliki keinginan untuk memulai suatu kerjasama, yaitu dengan selalu mempunyai keinginan untuk melakukan dan berusaha untuk tetap menjalin komunikasi antar kedua pihak. Ini dilakukan agar selalu ada komunikasi yang terbangun antar kedua pihak. Sehingga jika ada sesuatu yang salah dapat segera di tangani dengan baik. Selain itu kedua pihak harus dapat saling bertukar pengalaman, informasi maupun mengenai teknologi. Harus selalu mengingat bahwa sebagai mitra kerjasama harus melakukan tukar informasi terutama pada bidangbidang yang akan di kerjasamakan. Hal ini dapat membantu proses keberhasilan suatu program dalam kerjasama nantinya. Karena kerjasama yang akan benar-benar berjalan akan membuat keduanya berperan aktif sehingga dapat terwujud kerjasama yang bermanfaat.

Dalam hal kerjasama ini tidak hanya 2 belah pihak yang berperan dalam pencapaian tujuan, namun dukungan dari masyarakat sebagai objek kerjasama juga turut memberikan kontribusi dalam pencapaiannya. Jika dilihat dari dukungan masyarakat tidak sepenuhnya mendukung dan menerima kerjasama ini, ini dapat dilihat dari sengketa tanah yang akan dijadikan tempat PKS beroperasi. Tanah dimana akan didirikannya PKS merupakan kepemilikan pribadi dari Bupati terdahulu Jefry Noer, namun terdapat pihak lain yang mengklaim bahwa tanah tersebut masih dalam sengketa. Pada peletakan batu pertama pembangunan PKS terdapat aksi demo, salah satu pendemo, Rahmat dalam orasinya menyampaikan bahwa mereka menolak keras peletakan batu pertama pembangunan pabrik kelapa sawit tersebut karena masih menyisakan sejumlah persoalan.

"Tanah di dalam sana masih banyak yang belum diganti rugi" 20

Selain masalah kurangnya dukungan dari masyarakat terhadap pembangunan PKS ini, berakhirnya masa jabatan Bupati terlihat juga ikut mempengaruhi keberhasilan kerjasama ini. Selang setahun setelah peletakan batu pertama pembangunan PKS terjadi pergantian kepala daerah Kabupaten Kampar, ini juga mempengaruhi terhadap perjanjian kerjasama yang telah ditandatangani. Seperti yang dijelaskan oleh Yohanes Kasubag Pangan, Pertanian dan Perikanan

"banyak perjanjian kerjasama yang hingga saat ini tidak berjalan dan tidak ada tindak lanjut perkembangannya"

Berdasarkan pernyataan tersebut dapat dianalisis bahwa posisi pemerintah daerah dalam kerjasama luar negeri masih sebagai pelaksana sedangkan yang

\footnotetext{
${ }^{20}$ Peletakan Batu Pertama PKS Sungai Pinang Makan Korban, Demo Mahasiswa Di Pukuli Babak Belur dalam http://riauone.com/riau/sub/kampar/-Peletakan-Batu-Pertama-PKS-Sungai-Pinang-Makan-Korban---Demo-Mahasiswa-Di-Pukuli-Babak-Belur diakses pada tanggal 1 November 2017
} 
menentukan tetap pemerintah pusat. Tidak banyak kebijakan yang dapat ditindaklanjuti dalam kerjasama luar ketika pihak pusat belum memutuskan hal-hal yang terkait dengan pengurusan izin kerjama.

\section{B. Analisis Dampak Kerjasama}

Dampak kebijakan merupakan suatu upaya untuk mengetahui apa sesungguhnya yang telah dilakukan oleh institusi dan bagaimana cara mengimplementasikannya. Dampak kebijaka juga dibedakan antara policy impact outcomes dan policy output. Policy out comes adalah akibat-akibat dan konsekuensikonsekuensi yang ditimbulkan dengan dilakukannya kebijakan. Sedangkan policy output adalah apa yang telah dihasilkan dengan adanya proses perumusan kebijakan dari pengertian ini, maka dampak mengacu pada perubahan-perubahan yang diakibatkan oleh suatu implementasi kebijakan.

Berdasarkan analisis implementasi kerjasama antara Kabupaten Kampar dan MTDC melalui indikator seperti yang telah dikemukakan di atas, terdapat kedua indikator yang tidak terlaksana dengan baik, yaitu proses kerjasama dan pencapaian tujuan. Dari kedua indikator tersebut, peneliti akan menjabarkan dampak-dampaknya terhadap masyarakat kelompok sasaran didalam bagian ini.

Sebuah program dapat menimbulkan dampak positif maupun negatif dan kalau diamati dampak tersebut ada yang direncanakan maupun dampak yang tidak direncanakan. Program-program, baik yang memiliki dampak positif maupun dampak negatif merupakan kesempatan belajar untuk optimalisasi pendekatan dan implementasi ke depan. Upaya analisis implementasi ialah untuk menentukan dampak dari kebijakan pada kondisi kehidupan nyata. Dampak dapat dilihat pada perubahan kondisi baik secara fisik maupun sosial yang merupakan akibat dari hasil kebijakan.

Bisa dijelaskan jika melihat dari dampak secara fisik untuk kerjama ini tidak ada, pabrik kelapa sawit yang ingin dibuat tidak pernah terlaksana. Dari awal penandatangan MoU pada bulan Maret 2013, kemudian peletakan batu pertama bangunan pabrik yang sempat ramai diperbincangkan dikalangan masyarakat pada tahun 2015 hingga 2017 belum ada dampak yang signifikan terhadap kemajuan perekonomian masyarakat Kabupten Kampar.

Dampak lain yang bisa dijelaskan adalah dampak psikologis dari masyarakat Kabupaten Kampar khususnya kecamatan Kampar Timur sebagai daerah yang ditunjuk untuk pembangunan pabrik kelapa sawit percontohan pertama dari kerjasama ini. Berdasarkan hasil wawancara dari penduduk menjelaskan kekecewaan mereka pada pemerintah. Jika kerjasama ini terwujud penduduk tentu dapat merasakan dampak seperti yang dicita-citakan secara ekonomi dengan direktrutnya penduduk lokal sebagai pekerja pada pabrik tersebut.

Dan jika melihat tingkat perubahan yang dialami masyarakat tidak berdampak siknifikan karena memang implementasi kebijakan tidak berjalan dengan baik. Tanah yang yang menjadi pembangun PKS hingga kini tidak berjalan dengan baik dan tanah tersebut dijadikan kebun cabe oleh masyarakat. 


\section{SIMPULAN DAN SARAN}

Berdasarkan hasil analisa di bab sebelumnya, maka hasil penelitian dapat disimpulkan sebagai berikut:

1. Dalam analisis implementasi kerjasama luar negeri antara pemerintah Kabupaten Kampar dan MTDC dengan melihat pada 2 indikator yaitu proses kerjasama dan pencapaian tujuan dapat dikatakan tidak terlaksana. Hal ini dilihat dari 5 tahun berjalan setelah penandatangan MoU tidak mampu untuk mengimplementasikan pabrik kepala sawit yang diinginkan pada awal kerjasama. Selain itu terdapat beberapa hal yang menyebabkan tidak terimplementasinya kerjasama tersebut seperti: Lemahnya perjanjian MoU kerjasama. Terdapat praktek negara, khususnya pada negara-negara common law system, yang berpandangan bahwa MoU adalah non-legally binding. Artinya MoU yang ditandangani oleh kedua belah pihak masuk dalam kategori soft law yang tidak mengikat secara kuat. Selain itu terdapat isu penenaman investasi asing pada kerjasama ini. Dimana penerapan penanaman modal asing merupakan hak pemerintah pusat untuk memutuskan semua perizinan, dan ini menjadi kendala besar ketika kerjasama tidak terimplementasi. Selain itu jika dilihat dari pencapaian tujuan terdapat kurangnya dukungan dari masyarakat menyankut sengketa tanah serta peralihan kekuasaan Bupati Kampar.

2. Dampak Kerjasama luar negeri dapat dilihat pada perubahan kondisi baik secara fisik maupun sosial yang merupakan akibat dari hasil kebijakan. Dampak fisik: tidak ditemukan perubahan fisik terhadap pembangunan PKS. Penulis juga menemukan dampak Psikologis dari masyarakat yaitu berupa kekecewaan terhadap pemerintah yang belum mampu membuat kebijakan yang mampu meningkatkan perekonomian masyarakat.

\section{Saran}

Keterbatasan waktu yang dimiliki peneliti dalam melakukan penelitian nii menyebabkan penelitian ini tidak luput dari kelemahan-kelemahan. Dengan alasan tersebut maka peneliti mengeukakan saran-saran untuk penelitian selanjutnya sebagai berikut:

1. Menambah informan dari pihak MTDC agar mendapatkan informasi yang lebih jelas dan valid.

2. Melakukan penelitian lanjutan mengenai faktor-faktor penghambat implementasi kerjasama luar negeri kabupaten Kampar dengan MTDC

\section{Saran Praktis}

Selain saran metodologis, berdasarkan hasil penelitian yang telah diperoleh, peneliti dapat memberikan saran kepada pemerintah kabupaten Kampar untuk mengevaluasi kembali kerjasama luar negeri yang telah ditandatangani perjanjiannya, menindaklanjuti kerjasama jika dirasa mampu untuk meningkatkan perekomomian masyarakat dengan mengusahakan pengurusan izin di pihak pemerintah pusat, dan menyelesaikan kendala dalam proses kerjasama seperti sengkta tanah dengan pihak terkait. 


\section{DAFTAR PUSTAKA}

Adi, Rianto. 2005. Metodologi Penelitan Sosial dam Hukum. Jakarta: Granit.

Asikin, Zainal. 2011. Perjanjian Kerjasama Antara Pemerintah dan Swasta dalam Penyediaan Infrastruktur Publik. Nusa Tenggara Barat: Universitas Mataram.

Burchill, Scott dan Andrew Linklater. 1996 (ed. Revisi). Teori-teori Hubungan Internasional. Bandung: Nusa Media.

Broto, Mani Festati. 2015. Kerjasama Luar Negeri Oleh Pemerintah Daerah Menghadapi MEA (Kajian Paradiplomasi dalam Khasanah Ilmu Pemerintahan). Prosiding Universitas Terbuka.

Fontana, Avanti.2009. Innovate we can!. Jakarta: Gramedia.

Outlook Komoditi kelapa Sawit. Oleh Pusat data dan Informasi Pertanian Kesekretariat Jenderal. Kementrian Pertanian tahun 2014. ISSN 1907-1507.

Panduan Umum Tata Cara Hubungan dan Kerjasama Luar Negeri oleh Pemerintah Daerah (Revisi). 2006. Departemen Luar Negeri Republik Indonesia.

Retnaningsih, Umi Oktyari. 2006. Laporan Pelatihan Non Gelar. Pekanbaru: Universitas Riau.

Roisah, Kholid.2015. Hukum Perjanjian Internasional Teori dan Praktik. Malang: Setara Press

Jemadu, Aleksius. 2008. Politik Global, teori dan Praktek. Yogyakarta: Graha Ilmu.

Syahza, Almasdi. 2012. Potensi Pengembangan Kelapa Sawit. Pekanbaru: UNRI, (Hasil penelitian MP3EI tahun 2012 di Wilayah Riau).

Soeprapto. 1997. Hubungan Internasional: Sistem, Interaksi dan Pelaku. Jakarta: PT. Raja Grapindo Persada,

Asep Dadan Muhanda dalam Sawipac Malaysia Siap Bangun Pabrik Terpadu Olahan Sawit Di Riau (online) http://industri.bisnis.com/read/20140208/99/201893/sawipac-malaysia-siapbangun-pabrik-olahansawit-di-riau diakses pada tanggal 5 April 2015, pukul 12.05 di Pekanbaru

Netty Mindrayani dalam Investor Malaysia Bangun Pabrik Mentega Di Kampar (online) http://antarariau.com/berita/24556/investor-malaysia-bangun-pabrik-

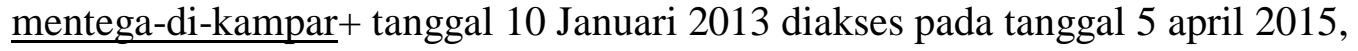
pukul 12.05 di Pekanbaru.

Potensi Kelapa Sawit di Kabupaten Kampar (online) http://regionalinvestment.bkpm.go.id/newsipid/commodityarea.php?ia=1406\&i $\underline{\mathrm{c}=2}$ diakses pada tanggal 5 April 2015 pukul 12.05 WIB di Pekanbaru

Mukhtar, Bangun Industri Hilir Kelapa Sawit, Malaysia Investasikan Rp. 1T di Kampar, April 25, 2013 (online) http://riaubisnis.com/bangun-industri-hilirkelapa-sawit-malaysia-investasikan-rp1-triliun-di-kampar/ diakses pada tanggal 9 April 2015.

Pekan ini, Harga TBS Kelapa Sawit Turun Rp41,40 Perkilogram. Selasa, 24 Maret 2015 (online) http://www.riauterkini.com/usaha.php?arr=89599\&judul=Pekan\%20ini,\%20Ha 
rga\%20TBS\%20Kelapa\%20Sawit\%20Turun\%20Rp41,40\%20Perkilogram diakses pada tanggal 10 April 2015 di Pekanbaru

Riyan Nofitra. Kampar Kini Punya Pabrik Olahan Kelapa Sawit. 10 Maret 2015. (online) http://www.tempo.co/read/news/2015/03/10/092648727/Kampar-KiniPunya-Pabrik-Olahan-Kelapa-Sawit diakses pada tanggal 10 April 2015 di Pekanbaru. 